УДК 551.34

\title{
МЕЖЗОНАЛЬНАЯ КОМПЛЕКСНАЯ УЧЕБНАЯ ПРАКТИКА СТУДЕНТОВ НАПРАВЛЕНИЯ 05.03.02 «ГЕОГРАФИЯ», ПРОФИЛЬ «ЭКОНОМИЧЕСКАЯ И СОЦИАЛЬНАЯ ГЕОГРАФИЯ» ВОРОНЕЖСКОГО ГОСУДАРСТВЕННОГО УНИВЕРСИТЕТА В РЕСПУБЛИКЕ АДЫГЕЯ
}

\author{
Н. В. Яковенко, И. В. Комов \\ Воронежский государственный университет, Россия \\ Поступила в редакиию 12 мая 2019 г.
}

\begin{abstract}
Аннотация: Статья раскрывает особенности проведения межзональной комплексной учебной практики студентов направления 05.03.02 «География», профиль «Экономическая и социальная география» Воронежского государственного университета в Республике Адыгея.
\end{abstract}

Ключевые слова: межзональная практика, студент, экономическая и социальная география.

Interzonal complex educational practice of students of the direction

05.03.02 «Geography», profile «Economic and social geography» of the Voronezh State University in the Republic of Adygea

\section{N. V. Yakovenko, I. V. Komov}

Abstract: The article reveals the features of the interzonal complex educational practice of students of the direction 05.03.02 «Geography», profile «Economic and social geography» of the Voronezh State University in the Republic of Adygea.

Key words: interzonal practice, student, economic and social geography.

В современном российском вузовском образовании приоритет отдается качественному профессиональному образованию, где ведущее место должна занимать практико-ориентированная подготовка [12]. Среди профильной подготовки высокопрофессионального выпускника географа важное место занимают учебные и производственные практики, среди которых межзональная комплексная учебная практика занимает одно из важных мест. На практике реализуется ее основная задача - соединение теоретических знаний студентов с практической научно-исследовательской деятельностью в различных физико-географических и социально-экономических условиях.

Практика проводится, как правило, в горных районах страны и имеет образовательный, познавательный и воспитательный потенциал, в течение практики студенты приобретают профессио-

() Яковенко Н.В., Комов И.В., 2019 нальные умения и навыки, происходит формирование важнейших личностных качеств студентов - коллективизма, ответственности, объективного восприятия действительности, повышения общепрофессиональной эрудиции. База практики кафедры социально-экономической географии и регионоведения в 2018 году находилась на полигоне ВГУ «Никель» в Республике Адыгея. Размещаются студенты в комфортабельных домиках-вагончиках.

Цель межзональной практики заключается в обобщении и закреплении теоретических знаний и практических навыков, полученных в ходе аудиторных занятий, выявлении и изучении особенностей и закономерностей развития, размещения и функционирования физико- и социально-экономических географических объектов и явлений на местности в полевой обстановке.

Отличительная особенность межзональной практики состоит в том, что ее маршрут проходит по разным природным зонам и охватывает обшир- 
ную территорию от южной части степной зоны России до предгорных участков Кавказских гор. Студенты изучают особенности природных зон, специфику хозяйственного освоения территории, традиции и быт населения, а также знакомятся с производственными предприятиями и туристскими объектами. В период практики студенты получают навыки организации краеведческой и экскурсионной работы.

Полевой период предполагает покомпонентное изучение природы. Так как район базы практики «Никель» в тектоническом отношении представляет собой зону новейшей складчатости, осложненную множеством разрывных нарушений в составе Пшекиш-Тырнаузской шовной зоны, то здесь студенты наблюдают изверженные породы разного возраста: от палеозоя до кайнозоя (метаморфические и осадочные). Изучают дизъюнктивные и пликативные нарушения залегания горных пород, угловые несогласия, формы складчатости [1]. Непосредственно в долине реки Белой изучаются разнообразные типы четвертичных террас, изменяющиеся под влиянием литолого-тектонических условий. В районе практики обнажаются терригенные отложения по долинам рек, балок и ручьев. Студенты проводят всестороннее литологическое описание, которое включает информацию о структуре, текстуре, размере зерна, цвете, минералогическом составе и общей классификации горных пород, дают характеристику мощности и площади распространения скальных пород [2]. В полевых условиях на примере делювиальных отложений изучаются оползневые тела и селевые явления. На примере элювиальных отложений (позднеюрские карбонатные породы) исследуются процессы карстообразования (карры, пещеры, подземные карстовые каналы). В районе практики имеется достаточно много искусственных горных выработок (карьеры, штольни, шурфы), на примере которых изучаются техногенные ландшафты. Ежедневно на маршруте студенты собирали образцы горных пород, залегающие в окрестностях. Одна из задач, стоящих перед студентами, состояла в том, чтобы по цвету, блеску и прочим признакам распознавать типы горных пород.

Во время полевого этапа студентами были закреплены теоретические знания и получены практические навыки ведения геоморфологических исследований, рассмотрены основные формы горного рельефа, освоено геоморфологическое профилирование и картографирование. Полевой этап практики проходил в две стадии. Во время первой стадии проводились геоморфологические исследования долины реки Белая в пределах базы практики «Никель». Вторая стадия практики проводилась во время экскурсионной поездки по Республике Адыгея для изучения форм равнинного и горного рельефа. Работы, проводимые на данном этапе: осмотр места исследования, выделение основных геоморфологических элементов, их описание, определение точек и пикетов нивелирной съемки, измерение координат точек съемки с помощью GPSнавигатора, измерение расстояния до пикетов при помощи лазерного дальномера, описание точек.

Студенты делают анализ орографических условий, которые оказывают влияние на развитие поселений, садоводства и огородничества, организацию мест отдыха населения, а также развитие инженерно-транспортной и социальной инфраструктур.

Изучая климатические особенности территории, студенты выполняют инструментальные измерения показателей состояния приземного слоя атмосферы. Программа микроклиматического изучения территории включает: измерение температуры и влажности воздуха, направления и скорости ветра, а также определение сопутствующих им облачности, интенсивности солнечного сияния и некоторых других атмосферных явлений, помогающих понять и оценить микроклиматические различия при разных типах погоды. Студенты строят карты хода температурного режима, осадков, климатического и агроклиматического районирования территории. Формулируют обобщенные выводы о влиянии климатических особенностей территории на развитие сельскохозяйственного производства.

Изучая гидрологические особенности территории, студенты дают общую характеристику бассейнов рек, проводят разные виды гидрометрических работ [4]. На территории республики находится около 5 тысяч рек и речушек, истоки которых находятся на Главном Кавказском хребте и его отрогах, относящихся к бассейну Азовского моря. Имеется более 4,7 тысяч малых рек длиной не более 25 км.

На территории Адыгеи насчитывается более 100 небольших озер, имеющие разнообразный генезис озерных котловин. Одним из водных объектов для изучения во время практики выступило карстовое озеро Псенодах, расположенное на плато Лагонаки в районе Фишт-Оштеновского массива. Озеро имеет форму полумесяца, и находится на дне обширного цирка, образовавшегося после ледникового периода. Псенодах расположено меж- 
Межзональная комплексная учебная практика студентов направления 05.03 .02 «еография», профиль «Экономическая и социальная география» Воронежского государственного университета в республике Адыгея

ду Фишт-Оштеновским массивом и горой ПшехоСу. В озеро впадает четыре ручья и семь подводных ключей, при этом ничего из Псенодаха не вытекает. Во время изучения студенты выполняют следующие виды работ: определяют размер озера и характер береговой линии; характеризуют грунт на отмелях, мощность иловых отложений; измеряют температуру воды на поверхности и на разных глубинах; изучают цвет, прозрачность и другие характеристики воды. Собирают данные о пересыхании, промерзании, заморах, наибольшем и наименьшем уровнях воды. Описывают водную и прибрежную растительность, а также видовой состав животного мира. Анализируют наличие притоков, истоков, прилегающих болот, ключей. Определяют источники загрязнения и меры защиты озера. Составляют картосхему озера.

Во время горного маршрута проводится изу-

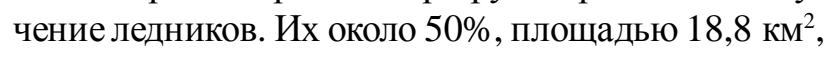
расположено в южной части Адыгеи на северных склонах вершин Главного и Бокового хребтов. Студенты изучают ледники горной группы ФиштаПшехо-Су, где сохранились 3 небольших ледника: Большой Фиштинский (площадь 0,7 км²$^{2}$, длина 1,2 км); Малый Фиштинский (один из самых низких ледников на Кавказе, высота 1980 м); ледники горы Пшехо-Су (высота 305 м, площадь 0,1 км²). Студенты измеряют их протяженность, мощность снегового покрова; изучают формы рельефа, обусловленные ледниковой деятельностью. Также проводят измерение длины и ширины ледника; проводят стандартные метеоклиматические наблюдения на поверхности ледника; проводят картирование мест загрязнения на водоисточниках.

Почвы Республики Адыгея представлены типичными черноземами, одними из самых плодородных в России. В структуре земельных угодий преобладают земли сельскохозяйственного назначения (43\%). На земли лесного фонда приходится $30 \%$, а на долю земель особо охраняемых территорий $-12 \%$, земли населенных пунктов $-6 \%$, земли промышленности, транспорта, связи и иного несельскохозяйственного назначения $-2 \%$, земли водного фонда $-6 \%$, земли запаса $-1 \%$ земельного фонда республики. Почвенный покров меняется по направлению к горам с возрастанием абсолютной высоты. Схема полевых исследований соответствует концепции структуры почвенного покрова: исследования маршрутно-ключевые. Для изучения закладывают ключи разных видов. Студенты, используя специальные руководства и методические указания, проводят описание почвенных профилей [11].
В рамках практики проводятся геоботанические исследования, что обусловлено спецификой территории Адыгеи. Основные наземные ландшафты Адыгеи представлены степью, лесостепью, широколиственными лесами, темнохвойными лесами, субальпийскими и альпийскими лугами, вечными снегами, субнивальной и нивальной зонами. Территория республики отличается высоким уровнем эндемизма и колоссальным видовым разнообразием. Видовой состав представлен кленом Траутветтера, рододендроном понтийским, черникой кавказской. Около 230 видов растений и грибов - редкие и исчезающие. Они занесены в Красную книгу Республики Адыгея $[6,9]$.

Во время маршрута студенты знакомятся с составом и структурой растительных сообществ Республики Адыгея, осваивают методы изучения растительного покрова, закрепляют навыки создания гербарных коллекций, определения видов растений, анализа геоботанических данных с помощью классических и современных методов. Студенты анализируют вид использования и степень изменения ландшафтного комплекса человеком. Дают характеристику специализации сельскохозяйственного производства, определяют качественный состав, продуктивность и степень эксплуатации пастбищ и леса.

Фауна Адыгеи насчитывает 384 вида позвоночных, 65 видов животных (помимо реликтовых и эндемичных форм), находится под угрозой исчезновения. Фауна млекопитающих насчитывает 81 вид, 11 из них занесены в Красную Книгу России и 17 - в Красную Книгу МСОП. В размещении животного населения, как и растительного покрова, четко выражен поясной характер. Во время маршрута отмечаются все встречи с позвоночными животными, определяется их видовой состав; проводится знакомство с фауной беспозвоночных (насекомые и паукообразные) и позвоночных. В рамках практики изучаются такие виды сельскохозяйственной деятельности населения как пчеловодство и рыбная ловля. Во время полевого периода проводится ландшафтная съемка территории и собирается материал для составления ландшафтно-оценочного отчета.

По результатам первого года организации межзональной комплексной практики в Адыгее намечен максимальный перечень маршрутов: 1. Долина реки Белая вверх до Гранитного ущелья. 2. Ущелье ручья Золотой. 3. Долина реки Белая вверх до водопада р. Коваленко, устье р. Сибирка. 4. Долина реки Белая вверх до поселка Гузерипль. 5. Ущелье реки Сюк до водопадов. 6. Долина реки Белая 
вниз до ущелья Грузинка. 7. Долина реки Белая до поселка Хаджох. 8. Каскад водопадов ущелья реки Руфабго. 9. Месторождение аммонитов (балка Полковничья). 10. Плато Лагонаки. 11. Автобусная экскурсия по Республике Адыгея с посещением уникального памятника природы Гуамского ущелья.

В рамках практики предусмотрены выездные экономико-географические маршруты, способствующие закреплению полученных навыков и умений самостоятельной научно-исследовательской деятельности студентов. Были организованы экскурсии в города Майкоп и Белореченск, поселки Гузерипль, Каменомостский и станицу Даховскую. Ознакомительная экскурсия по Национальному музею Республики Адыгея в городе Майкоп - это важнейший и единственный республиканский научно-методический центр, дала возможность получить студентам значительное количество информации и систематизировать данные о естественно-историческом, культурно-бытовом, хозяйственно-экономическом развитии как города, так и республики.

Таким образом, будущие географы закрепляли полученные теоретические знания на практике. Студенты, вооруженные топографическими картами, пакетами для образцов пород и гербарными сетками, приборами для измерений, с запасом еды в рюкзаках, каждый день осуществляли радиальные маршруты в разных направлениях. Вечером, в камеральной комнате (а это веранда на открытым воздухе под тентом), вернувшиеся из похода студенты обрабатывали полученную информацию, слушали лекции руководителей и систематизировали образцы собранных горных пород и растений, а также обрабатывали материалы, собранные ими на маршруте.

На территории региона имеется индустриальное и горнотехническое сырье. В рамках практики студенты посетили Глубокохаджокское месторождение красных глин, которое используется для изготовления клинкерного кирпича, Блокгаузное месторождение гранитов, Фарское и Шушукское месторождения гипса. Эти месторождения являются базовыми для предприятий «Волма» и «Кубань-Кнауф», специализация которых - производство строительно-отделочных материалов [7].

Также состоялась экскурсия на Мишокское месторождение, где добываются высококачественные известняки, используемые сахарными заводами юга России.

Проведенные 2 дня в Майкопе дали возможность студентам непосредственно на производстве познакомиться с технологическим процессом по производству пива и блоков для строительства, рассмотреть хозяйственный и культурный облик Республики Адыгея в рамках экскурсии.

Состоялась экскурсия на Пивоваренный завод - одно из градообразующих предприятий города Майкопа. Продукция завода востребована далеко за пределами России. В производственных условиях студенты восстановили знания по дисциплине «Технико-экономические основы производства».

Адыгея - многоконфессиональный регион. Здесь мирно сосуществуют христиане и мусульмане разных толков. Посещение Мечети в городе Майкопе дало возможность познакомиться с обычаями, традициями и верованиями гостеприимного и приветливого народа [7].

Социологический опрос, проведенный студентами на территории самого большого бассейна Европы (длина которого составляет 500 м), дал возможность определить наболевшие и злободневные проблемы Южного региона России.

Знакомство с плодоводческим комплексом «Хаджох» показало студентам, что промышленное плодоводство - выращивание яблок высших товарных сортов с целью развития импортозамещения, становится одной из экспортных отраслей Республики Адыгеи, что будет способствовать росту ее социально-экономического потенциала. Культура адыгейского садоводства имеет чрезвычайно древние корни. При раскопках археологического комплекса Псенафа был обнаружен керамический сосуд с изображением яблоневого сада, датируемый II веком до нашей эры.

В один из дней практики наша группа отправилась на горное плато Лагонаки - природный комплекс с неповторимыми чертами, отличающимися даже от многообразной природы Кавказа. На Лагонакском нагорье сформировался уникальный микрорегион с особыми геологическими условиями. Появление особых ландшафтов - это последствия формирования известняково-доломитовых толщ. Рельеф уникален в своем разнообразии: высокогорные скалистые массивы во главе с горой Фишт и ее ледниками $(2853,9$ м), средневысотные облесенные хребты и плато с небольшим уклоном, изрезанные ледниками. Скалистые массивы разнообразны по своему происхождению: Пшеха-Су и Оштен обрели свой вид в результате деятельности льда, карста и морозов; Каменное море карстового происхождения, обрывы южной экспозиции Оштена образованы после землетрясения. Флора плато очень эндемична, особенно 
Межзональная комплексная учебная практика студентов направления 05.03 .02 «еография», профиль «Экономическая и социальная география» Воронежского государственного университета в республике Адыгея

Каменного моря, включает 405 видов растений, из них 124 эндемика. Удивительным кажется и то, что Лагонакское нагорье - это единственная территория, расположенная на склоне Северного Кавказа, где растет самшит. Использование объекта в рекреации возможно благодаря многообразию рекреационных ресурсов. К таким ресурсам относятся памятники природы, минеральные источники, пейзажно-эстетический потенциал территории [7].

На плато Лагонаки студенты посетили древнюю и уникальную карстовую Азишскую пещеру. Этой пещере около 2-х млн. лет. Однако полностью она сформировалась около 10 тыс. лет назад. Обнаружена она была в середине XIX-го века. Здесь уникальный микроклимат и особая энергетика. Биоэнергеты, парапсихологи, утверждают, что в таких пещерах можно поправить свое здоровье. Например, есть шанс излечиться от таких заболеваний, как астма, аллергия.

Одно из наиболее ярких впечатлений от практики - это 2-х дневный горный переход. Республика Адыгея и Краснодарский край имеют высокий потенциал для развития туристской активности: гора Фишт, гора Оштен, гора Большой Тхач, гора Чугуш. Маршрут проходил по линии поселок Никель - поселок Гузерипль - КПП Узуруп приют Фишт - КПП Узуруп. Гора Фишт расположена в западной части Кавказского хребта. Вместе с пиками Оштен и Пшеха-Су она образует Фишт-Оштенский массив - первый с запада на восток массив Кавказа с альпийскими и субальпийскими горными лугами. Высота горы достигает 2867 м - это наивысшая точка плато Лагонаки. Западный участок примечателен небольшим понижением, откуда ниспадает ручей Водопадистый, заканчивающийся невероятным Пшехским водопадом, его высота составляет 160 м, он один из наивысших на территории России. Гора Фишт славится своей уникальной флорой: здесь произрастает около 700 растений, среди которых $25 \%$ - эндемики. Бытует мнение, что она некогда была островом, расположенным в древнем океане Тетисе, существовавшем в эпоху мезозоя. Гора Фишт сложена известняками, из-за чего в ее толще образовалось множество воронок, подземных миникаскадов, озер и карстовых полостей. Известнейшие гроты - «Белая звездочка» («Крестик-турист»), «Парящая птица», «Англо-русская» и «Ольга».

Среди основных особенностей («чудес») горы Фишт можно выделить следующие: 1) пещера «Крестик-турист» - самая глубокая в России (глубина 650 метров, длина подземных ходов - боль- ше 16 километров); 2) высочайший в России водопад - Пшехский (высота около 160 метров); 3) Малый ледник - самый низкий на Кавказе (1980 мм над уровнем моря) и самый восточный ледник в Европе; 4) река, которая внезапно исчезает, и также мгновенно появляется на поверхности. Начало ее находится у водопада, у западной стены горы, и далее она «переходит из мокрого русла в сухое»; 5) наличие растений эндемиков, которые произрастают только здесь; 6) коралловый остров (окаменелые фауна и флора океана Тетис); 7) Фиштинская котловина - «самое мокрое место России» (здесь после обеда либо идет дождь, либо снег) [6].

Самой популярной и колоритной природной достопримечательностью Адыгеи являются водопады Руфабго - это уникальный памятник природы, расположенный в ущелье реки Руфабго - одном из притоков реки Белая. Всего насчитывается 10 водопадов, но самыми посещаемыми и красочными являются водопады Шум, Каскадный, Сердце Руфабго, Шнурок (Девичья Коса), Чаша любви и Девичьи Косы [1].

Одним из объектов изучения явилось Гуамское ущелье узкое глубокое ущелье в верховьях реки Курджипс. Ущелье расположено между хребтами Гуама и Лагонаки, резко обрываясь четырехсотметровыми скалами к долине реки Курджипс. Находится на территории Апшеронского района Краснодарского края. В пределах Гуамского ущелья река Курджипс падает на 95 метров. Длина Гуамского ущелья - 3 километра, а его глубина - 400 метров. Площадь его составляет 338,8 га. Это уникальный геологический музей-заповедник, который не имеет аналогов во всем мире. В каньоне уникально все: геологическое строение, реликтовая флоpa, редчайшие представители фауны. Гуамское ущелье - это ландшафтный памятник природы. Имеет заповедный режим охраны с 1978 года [2]. В районе ущелья интенсивно проявляются следующие современные экзогенные процессы: глубинная эрозия, карст, оползни, селепроявления, обвалы, осыпи. Тектоническая трещиноватость в ущелье способствует образованию крупных излучин. Деятельность реки Курджипс углубляет ущелье, что приводит к увеличению крутизны его склонов и активизирует склоновые процессы. Среди экзогенных процессов в ущелье наиболее развиты карстовые процессы. В районе ущелья известно около десяти пещер и гротов. Необычная цветовая гамма геологических пластов, в которой перемешаны синие, красные, белые, черные, свинцовые и дымчатые цвета, придает неповторимость Гуам- 
скому ущелью. Возраст самых древних пластов более 100 миллионов лет. Внизу, у самой реки, растет самшит. Чуть выше, на осыпях, - краснолистник и тис. На горных склонах встречаются: дуб, пихта, сосна, заросли можжевельника и шиповника, кусты азалии, рябины и жасмина. Гуамское ущелье - это крупнейший рефугиум колхидской флоры на Северном Кавказе [9].

Для пешеходных прогулок по Гуамскому ущелью вдоль узкоколейки идет песчаная аллея, огороженная бордюром от крутых порогов реки Курджипс. Самым уникальным природным объектом является 100 метровый водопад, малопосещаемый туристами. Он сначала падает каскадами, а затем трансформируется в одну 60-метровую струю, скатывается на край дороги слева, рассыпается на «белокурые» косы, срывается в узкий и глубокий каньон. В этом месте всегда дует сильный ветер. В Гуамском ущелье имеется крайне удивительная скала, оформленная природой, имеющая четкий профиль В.И. Ленина $[2,8]$. В окрестностях Гуамского ущелья есть интересные объекты, имеющие эстетическую и познавательную ценность необыкновенно красивый каньон Сухой Балки с водопадами, гротами и скалами и Монахова пещера.

За многие годы проведения учебных практик на факультете географии, геоэкологии и туризма сложилась традиция - знакомиться с культурноисторическими памятниками, расположенными в пределах разумной досягаемости от базы практики. Практика в Адыгее не исключение. Так состоялся маршрут по местам боевой славы «Партизанские тропы». В этих районах во время Великой Отечественной войны общими усилиями воинов разных национальностей были остановлены немецко-фашистские захватчики, и началось освобождение Северного Кавказа.

Экскурсия в Свято-Михайло-Афонский монастырь, или Михайловский мужской монастырь, находящийся рядом с Хаджохом - поселком Каменномостским. Паломники и туристы стекаются к Михайло-Афонскому монастырю и святому источнику со всей страны. Свято-Михайло-Афонский монастырь - самый высокогорный монастырь в России. Монастырь стоит на горе Физиабго, и вся гора под монастырем испещрена потайными ходами и таинственными пещерами. Когда-то у монахов под землей были мастерские иконописные и богатейшие библиотеки, а также святилище святых мощей. Посещение этого объекта религиозного туризма дало возможность студентам познакомиться не только с религиозной, но и с истори- ко-культурной, а также художественной ценностью этого места, получить новые знания, по-новому оценить окружающую действительность.

Состоялась ознакомительная экскурсия к термальным источникам, и непосредственно «Водной Ривьере», которая находится недалеко от поселка Каменномостский. Термальные минеральные источники подразделяются на теплые $\left(20-37^{\circ} \mathrm{C}\right)$, горячие $\left(37-50^{\circ} \mathrm{C}\right)$ и очень горячие $\left(50-100^{\circ} \mathrm{C}\right)$. Из $^{\circ}$ каждого бассейна были взяты пробы воды. По химическому составу и другим показателям образцы воды из разных бассейнов практически одинаковые [4]. Во время посещения был проведен социологический опрос отдыхающих на тему «Анализ степени удовлетворенности представленными услугами комплекса «Водная Ривьера».

Одним из моментов практики явилось ознакомление с технологией производства адыгейского сыра - национального блюда черкесской кухни [7]. Также были закреплены туристские навыки и умения студентов, из которых отметим сплав на байдарках по реке Белая в районе станицы Даховская, посещение Экстрим-парка «Мишоко» с целью апробации первичных навыков скалолазания (со страховкой) и переправы над ущельем глубиной более 100 метров.

В заключение следует отметить, что избранный вид практики дает возможность студентам понять правильность своего профессионального выбора, закрепить теоретические знания и умения, полученные в процессе обучения, определить профессионально важные качества будущей специальности. Практика формирует личностные качества студенты, среди которых основными являются тактичность, толерантность, выдержка, психологическая устойчивость; развивает коммуникативные и организаторские способности, необходимые географу профиля «Экономическая и социальная география». Практико-ориентированная подготовка будущего экономико-географа - это одна из базовых сторон учебного процесса. При прохождении различного рода практик студенты получают ценный практико-прикладной опыт, закрепляют и совершенствуют универсальные, обще- и профессиональные компетенции.

\section{СПИСОК ЛИТЕРАТУРЫ}

1. Бормотов И. В. В горах Адыгеи / И. В. Бормотов. - Пятигорск : Картинформ, 2003.

2. Бормотов И. В. Горная Адыгея / И. В. Бормотов. - Майкоп : Качество, 2009. - 182 с.

3. Земля адыгов / А. Х. Шеуджен [и др.]. - Майкоп : ГУРИПП Адыгея, 2004. - 1004 с. 
Межзональная комплексная учебная практика студентов направления 05.03 .02 «еография», профиль «Экономическая и социальная география» Воронежского государственного университета в республике Адыгея

4. Корнакова Н. В. Наша родина - Адыгея. Природа, население, хозяйство, история : учебное пособие / Н. В. Корнакова. - Ростов-на-Дону : БАРО-ПРЕСС, 2014. -448 c.

5. Красная книга Республики Адыгея : редкие и находящиеся под угрозой исчезновения объекты животного и растительного мира / Министерство охраны окружающей среды и природных ресурсов республики Адыгея. - Майкоп : Адыгея, 2000. - 415 с.

6. Литвинская С. А. Памятники природы Краснодарского края / С. А. Литвинская, С. П. Лозовой. - Краснодар : Периодика Кубани, 2005. - 325 с.

7. Ногмов Ш. Б. История адыхейского народа: составленная по преданиям кабардинцев / Ш. Б. Ногмов. - Нальчик : Эльбрус, 1994. - 231 с.

8. Особо охраняемые территории Республики Адыгея. - URL : http://www.adygheya.ru/tourism/guard/ index.shtml.

9. Памятников природы в Адыгее стало больше // ЭКОСинформ. - 2004. - № 11. - С. 53-54.

10. Погребицкая И. Э. Последствия строительства, эксплуатации и реконструкции узкоколейной железной дороги в Гуамском ущелье Краснодарского края и Республики Адыгея / И. Э. Погребицкая, Д. Ю. Шуляков // Вестник Воронежского государственного университета. Сер. География. Геоэкология. - 2018. - № 1. - С. 25-30.

11. Трепет С. А. Горная Адыгея / С. А. Трепет. Краснодар : Кубанское книжное издательство, 2013. $96 \mathrm{c.}$

12. Федотов В. И. Современная модель университетского экологического образования / В. И. Федотов, С. А. Куролап // Вестник Воронежского государственного университета. Сер. Проблемы высшего образования. - 2017. - № 3. - С. 14-18.

\section{REFERENCES}

1. Bormotov I. V. V gorakh Adygei / I. V. Bormotov. Pyatigorsk : Kartinform, 2003.

\section{Яковенко Наталия Владимировна}

доктор географических наук, профессор, заведующий кафедрой социально-экономической географии и регионоведения факультета географии, геоэкологии и туризма Воронежского государственного университета, г. Воронеж, т. +7 (473)266-56-54, E-mail: n.v.yakovenko71@gmail.com

Комов Игорь Владимирович

кандидат географических наук, доцент кафедры социально-экономической географии и регионоведения факультета географии, геоэкологии и туризма Воронежского государственного университета, г. Воронеж, т. +7(473)266-56-54, E-mail: igrkom@bk.ru
2. Bormotov I. V. Gornaya Adygeya / I. V. Bormotov. Maykop : Kachestvo, 2009. - 182 s.

3. Zemlya adygov / A. Kh. Sheudzhen [i dr.]. - Maykop : GURIPP Adygeya, 2004. - 1004 s.

4. Kornakova N. V. Nasha rodina-Adygeya. Priroda, naselenie, khozyaystvo, istoriya : uchebnoe posobie / N. V. Kornakova. - Rostov-na-Donu : BARO-PRESS, 2014. - $448 \mathrm{~s}$.

5. Krasnaya kniga Respubliki Adygeya : redkie i nakhodyashchiesya pod ugrozoy ischeznoveniya ob"ekty zhivotnogo i rastitel'nogo mira / Ministerstvo okhrany okruzhayushchey sredy i prirodnykh resursov respubliki Adygeya. - Maykop : Adygeya, 2000. - 415 s.

6. Litvinskaya S. A. Pamyatniki prirody Krasnodarskogo kraya / S. A. Litvinskaya, S. P. Lozovoy. - Krasnodar : Periodika Kubani, 2005. - 325 s.

7. Nogmov Sh. B. Istoriya adykheyskogo naroda: sostavlennaya po predaniyam kabardintsev / Sh. B. Nogmov. - Nal'chik : El'brus, 1994. - $231 \mathrm{~s}$.

8. Osobo okhranyaemye territorii Respubliki Adygeya. - URL: http://www.adygheya.ru/tourism/guard/index.shtml.

9. Pamyatnikov prirody v Adygee stalo bol'she // EKOSinform. - 2004. - № 11. - S. 53-54.

10. Pogrebitskaya I. E. Posledstviya stroitel'stva, ekspluatatsii i rekonstruktsii uzkokoleynoy zheleznoy dorogi v Guamskom ushchel'e Krasnodarskogo kraya i Respubliki Adygeya / I. E. Pogrebitskaya, D. Yu. Shulyakov // Vestnik Voronezhskogo gosudarstvennogo universiteta. Ser. Geografiya. Geoekologiya. - 2018. - № 1. - S. 25-30.

11. Trepet S. A. Gornaya Adygeya / S. A. Trepet. Krasnodar : Kubanskoe knizhnoe izdatel'stvo, 2013. - 96 s.

12. Fedotov V. I. Sovremennaya model' universitetskogo ekologicheskogo obrazovaniya / V. I. Fedotov, S. A. Kurolap // Vestnik Voronezhskogo gosudarstvennogo universiteta. Ser. Problemy vysshego obrazovaniya. 2017. - № 3. - S. 14-18.

Yakovenko Nataliya Vladimirovna

Doctor of Geographical Sciences, Professor, Head of the Department of social and economic geography and regional studies of the Faculty of Geography, Geoecology and Tourism, Voronezh State University, Voronezh, tel. +7(473)266-56-54, E-mail: n.v.yakovenko71@gmail.com

Komov Igor Vladimirovitch

Candidate of Geographical Sciences, Associate Professor of the Department of social and economic geography and regional studies of the Faculty of Geography, Geoecology and Tourism, Voronezh State University, Voronezh, tel. +7(473) 266-56-54, E-mail: igrkom@ bk.ru 